\title{
PENGARUH JENIS DAN KONSENTRASI BAHAN PENSTABIL TERHADAP MUTU FISIK KIMIA DAN SENSORIS VELVA BUAH MELON (Cucumis melo L.)
}

\author{
THE INFLUENCE OF TYPES AND CONCENTRATION OF STABILITY ON PHYSICAL, \\ CHEMICALS AND SENSORY OF MELON VELVA (Cucumis melo L.)
}

\author{
Dayanti Haryono, Rofandi Hartanto, Bara Yudhistira \\ Jurusan Ilmu dan Teknologi Pangan, Fakultas Pertanian, Universitas Sebelas Maret, Surakarta \\ E-mail: dayantihar@gmail.com
}

Diserahkan [24 Desember 2018]; Diterima [3 Maret 2020]; Dipublikasi [4 Maret 2020]

\begin{abstract}
Alternative dessert for people who suffer from cow's milk allergy, lactose intolerance, and low-fat diet, then made a dessert that has a low fat content, namely fruit velva. Fruit velva can be made from fruit that contains high dissolved solids, namely melon. Velva fruit is expected to be fine-textured and not to melt quickly and to add stabilizers. The stabilizers are carrageenan, arabic gum, and guar gum. The purpose of this study was to determine the effect of the use of types and concentrations of stabilizers on velva melon. This study uses a completely randomized design (CRD) of one factor, namely a combination of carrageenan, arabic gum, and guar gum with the treatment of two sample repetitions and three times repetition of analysis. All research data were analyzed using One Way Analysis of Variance (ANOVA) using SPSS. If the results show that there is a real difference between treatment then continue with Duncan's Multiple Range Test (DMRT) at $\alpha=0.05$. Based on the best formulation weighting test that is F4 (0.5\%, Arabic gum $0.25 \%$, guar gum $0.25 \%)$ with the result that the viscosity is $1630.87 \mathrm{cP}$; dissolved solids $19.10^{\circ}$ Brix, overrun $24.87 \%$; long melting 8.60 minutes; water content 77.61\%; vitamin C levels 22,45 mg / 100gr; dietary fiber content of 2.31\%; antioxidant activity 3.98\%; scores for sensory analysis in general panelists liked velva melon with each aroma score 3.60; taste of 4.08; texture $4.32 ; 4.48$ colors, and 4.24 overall.
\end{abstract}

Keywords: velva, melon, carrageenan, arab gum, guar gum

\section{ABSTRAK}

Alternatif dessert untuk masyarakat yang menderita alergi susu sapi, intoleransi laktosa, dan diet rendah lemak, maka dibuatlah dessert yang mempunyai kandungan rendah lemak yaitu velva buah. Velva buah dapat dibuat dari buah yang mengandung padatan terlarut tinggi yaitu melon. Velva buah diharapkan bertekstur halus dan tidak cepet meleh makan ditambahkan bahan penstabil. Bahan penstabilnya yaitu karagenan, gum arab, dan guar gum. Tujuan penelitian ini untuk mengetahui pengaruh penggunaan jenis dan konsentrasi bahan penstabil terhadap velva buah buah melon. Penelitian ini menggunakan Rancangan Acak Lengkap (RAL) satu faktor yaitu kombinasi karagenan, gum arab, dan guar gum dengan perlakuan dua kali pengulangan sampel dan tiga kali pengulangan analisis. Semua data hasil penelitian dianalisis menggunakan One Way Analysis of Variance (ANOVA) dengan menggunakan SPSS. Apabila hasil menunjukkan ada perbedaan nyata anatar perlakukan maka dilanjutkan dengan Duncan's Multiple Range Test (DMRT) pada $\alpha=0.05$. Berdasarkan uji pembobotan formulasi terbaik yaitu F4 (0,5\%, gum arab 0,25\%, guar gum 0,25\%) dengan hasil yaitu viskositas $1630,87 \mathrm{cP}$; padatan terlarut $19,10^{\circ}$ Brix, overrun $24,87 \%$; lama leleh 8,60 menit; kadar air $77,61 \%$; kadar vitamin C 22,45 mg/100gr; kadar serat pangan 2,31\%; aktivitas antioksidan 3,98\%; skor untuk analisa sensoris secara umum panelis menyukai velva melon dengan masing-masing skor aroma 3,60; rasa 4,08; tekstur 4,32; warna 4,48, dan overall 4,24.

Kata kunci: velva, melon, karagenan, gum arab, guar gum

\section{PENDAHULUAN}

Pertumbuhan penduduk Indonesia setiap tahunnya terus meningkat, sehingga menyebabkan terus berkembangannya industri bidang pangan untuk memenuhi kebutuhan makanan masyarakat. Industri dibidang pangan salah satu olahannya yaitu dessert. Dessert yang sangat digemari masyarakat adalah es krim, es krim adalah frozen dessert yang terbuat dari campuran susu, lemak nabati atau hewani, dan gula. Lemak susu yang digunakan berkisar 10 hingga 16\% (Hartatie, 2011). Akan tetapi karena kandungan lemak yang tinggi maka es krim tidak dapat dikonsumsi oleh orang yang yang sedang diet rendah lemak, alergi susu sapi, dan intoleransi laktosa. Agar orang yang diet rendah lemak, alergi susu sapi, dan intoleransi laktosa dapat mengonsumsinya 
maka dibuatlah velva buah, velva buah biasanya dibuat dari buah yang mengandung banyak padatan terlarut, salah satunya buah melon.

Buah melon sendiri sangat digemari masyarakat dan produksinya cukup tinggi karena mudah ditemukan. Kandungan air pada melon cukup tinggi yaitu 90,15 gr per 100 gr (USDA, 2016). Kandungan yang cukup tinggi tersebut dapat memicu pertumbuhaan mikroba dan memperpendek umur simpannya. Oleh karena itu perlu dilakukan pengolahan lebih lanjut untuk memperpanjang umur simpan buah melon, serta untuk memperoleh oalahan buah melon dengan kandungan buah yang lebih tinggi salah satunya yaitu dengan pembuatan velva buah melon.

Velva buah merupakan makanan pencuci mulut beku (frozen dessert) yang dibuat dari bahan dasar buah-buahan, bentuk velva buah seperti es krim. Namun masalah dalam pembuatan velva yang sering dihadapi yaitu bertekstur kasar dan cepat meleleh. Tekstur halus dan tidak cepat meleleh dapat diperoleh dengan penambahan bahan penstabil, bahan penstabil adalah suatu polimer yang larut dalam air, yang mampu membentuk koloid dan mampu mengentalkan larutan atau dapat membentuk gel dari larutan tersebut dan berfungsi untuk mencegah pembentukan kristal es (Nuraini, 2001). Bahan penstabil dibagi menjadi dua tipe yaitu hewani seperti gelatin dan nabati seperti alginate, agar-agar, CMC, karagenan, gom (gum arab dan guar gum) (Arbuckle, 1986).

Karagenan berasal dari rumput laut yang didapat dari ekstrak rumput laut merah, sehingga karagenan kaya akan serat. Kelebihan karagenan yaitu gel yang kuat, mudah larut dalam air, viskositas tinggi, mencegah wheying off, daya ikat air tinggi, dan tidak berwarna. Karagenan adalah agen pembentuk gel, sehingga dapat menghambat pertumbuhan kristal es yang beukuran besar. Cara penghambatannya dengan cara penurunan mobilitas air yang disebabkan oleh retensi air (Regand dan Goff, 2003. Gum arab adalah bahan penstabil yang berasal dari getah pohon akasia pada bagian batang atau rantingnya. Kelebihan dari gum arab yaitu mempunyai kelarutan pada air yang sangat tinggi dibandingkan bahan penstabil lainnya, bersifat penggabung, dan dapat mempertahankan rasa dan aroma (Tantono, Effendi, dan Hamzah, 2017).

Guar gum merupakan bahan penstabil yang digunakan pada es krim yang berasal dari biji tanaman legume Tetragonolobus cyamopsis. Kelebihan dari guar gum yaitu mudah larut dalam air dingin, mampu mengikat air, viskositas tinggi, mempertahankan emulsi, mampu memperbaiki kekuatan gel dan mencegah pembentukan kristal es yang besar. Perlu adanya penelitian terkait pengaruh jenis dan konsentrasi bahan penstabil untuk mendapatkan produk velva buah melon yang bertekstur halus dan tidak mudah meleleh. Tujuan dari penelitian ini yaitu mengetahui pengaruh jenis dan konsentrasi bahan penstabil terhadap mutu fisik, mutu kimia, dan sensoris velva buah melon.

\section{METODE PENELITIAN}

\section{Bahan}

Bahan velva buah yaitu buah melon, asam sitrat (cap gajah), karagenan, gum arab, guar gum, gula (gulaku).

Bahan analisis adalah kadar serat pangan buffer Na-phospat $\mathrm{pH}$ 6, enzim alpha amilase, enzim pepsin $1 \%$, asam klorida $1 \mathrm{~N}$ (HCL), natrium hidroksida $(\mathrm{NaOH})$, ethanol $95 \%$, aseton $\left(\mathrm{CH}_{3}\right)_{2} \mathrm{CO}$, enzim beta amilase. Vitamin $\mathrm{C}$ menggunakan iodin $0.01 \mathrm{~N}$ dan amilum. Aktivitas antioksidan dengan menggunakan DPPH dan metanol.

\section{Tahapan Penelitian}

\section{Persiapan Sampel}

Buah melon dikupas, dicuci, dipotongpotong ukuran $20 \mathrm{~mm}$ x $20 \mathrm{mmx} 20 \mathrm{~mm}$ dan ditimbang $300 \mathrm{~g}$, kemudian buah melon diblanching dengan suhu $\pm 90^{\circ} \mathrm{C}$ selama 3 menit. Setelah blanching dilakukan pemblenderan dengan penambahan air $75 \mathrm{ml}$ dan kemudian dilakukan pencampuran yang ditambahakan gula $75 \mathrm{~g}$, asam sitrat $0,3 \mathrm{~g}$, bahan penstabil 3,75 g (karagenan, guar gum, gum arab). Proses selanjutnya aging selama 24 jam, kemudian pembekuan dengan Ice Cream Maker (ICM) selama 30 menit dan 
langkah terakhir yaitu freezing dengan freezer selama 8-12 jam.

Formulasi yang digunakan masingmasing sebagai berikut F0 (0\% karagenan: $0 \%$ gum arab: 0\% guar gum), F1 (1\% karagenan: $0 \%$ gum arab: $0 \%$ guar gum), F2 (0\% karagenan: 1\% gum arab: $0 \%$ guar gum), F3 (0\% karagenan: 0\% gum arab: $1 \%$ guar gum), F4 (0,5\% karagenan: $0,25 \%$ gum arab: $\quad 0,25 \%$ guar gum), F5 $(0,25 \%$ karagenan: $0,5 \%$ gum arab: $0,25 \%$ guar gum $), \quad F 6(0,25 \%$ karagenan: $0,25 \%$ gum arab: $0,5 \%$ guar gum).

\section{Metode analisis}

Parameter uji fisik yaitu viskositas (Brookfield viscometer), padatan terlarut (AOAC, 1995), overrun (Marshal dan Arbuckle, 1996), lama leleh (Bodyfelt et al, 1998). Parameter uji kimia yaitu kadar air (AOAC, 1995), serat pangan (Asp et al, 1983), vitamin C (Iodometri), aktivitas antioksidan (DPPH). Uji sensoris (Larmond, 1977) dan penentuan formula terbaik (Sullivan et al, 1999).

\section{Analisis Statistik}

Data hasil uji fisik, kimia, sensoris dianalisis menggunakan one way ANOVA untuk mengetahui ada tidaknya perbedaan setiap perlakuan. Jika data hasil analisis terdapat perbedaan antar perlakuan maka dilanjutkan dengan uji beda nyata Duncan's Multiple Range Test (DMRT) pada taraf signifikansi $\alpha=0,05$.

\section{HASIL DAN PEMBAHASAN}

\section{Karakteristik Fisik}

\section{Viskositas}

Viskositas adalah ketahanan suatu zat cair untuk mengalir (Violisa, Nyoto, dan Nurjanah, 2012). Berdasarkan Tabel 1 jumlah dan konsentrasi bahan penstabil berbeda nyata. Hasil uji didapatkan semakin tinggi konsentrasi karagenan pada campuran bahan penstabil, maka viskositas meningkat. Hasil adonan velva paling kental yaitu karagenan $0,5 \%$, gum arab $0,25 \%$, dan guar gum $0,25 \%$, karena karagenan bersifat polielektrolit. Polielektrolit mengakibatkan gaya tolakan antar muatan-muatan negatif sepanjang rantai polimernya yang mengakibatkan rantai molekul menegang karena sifat hidrofiliknya sehingga polimernya dikelilingi oleh molekul-molekul air yang termobilisasi yang membuat larutan menjadi kental. Jika konsentrasi karagenan semakin meningkat maka viskositas akan meningkat secara logaritmi ((Agustin, dan Putri, 2014), (Basito dkk, 2018)).

Tabel 1 Hasil Uji Karakteristik Fisik Velva Buah Melon

\begin{tabular}{|c|c|c|c|c|}
\hline Formulasi & $\begin{array}{l}\text { Viskositas } \\
(\mathrm{cP}) *\end{array}$ & $\begin{array}{c}\text { Padatan } \\
\text { Terlarut }\left({ }^{\circ} \text { Brix }\right)^{*}\end{array}$ & $\begin{array}{c}\text { Overrun } \\
(\%)^{*}\end{array}$ & $\begin{array}{l}\text { Lama leleh } \\
\text { (menit)* }\end{array}$ \\
\hline F0 & $669,75^{\mathrm{a}}$ & $8,27^{\mathrm{a}}$ & $10,33^{\mathrm{a}}$ & $6,20^{\mathrm{a}}$ \\
\hline $\mathrm{F} 1$ & $1459,92^{\mathrm{d}}$ & $17,57^{\mathrm{cd}}$ & $16,64^{b}$ & $7,60^{\mathrm{c}}$ \\
\hline $\mathrm{F} 2$ & $1121,33^{b}$ & $13,23^{\mathrm{b}}$ & $19,47^{\mathrm{d}}$ & $6,79^{\mathrm{b}}$ \\
\hline $\mathrm{F} 3$ & $1360,65^{\mathrm{c}}$ & $17,27^{\mathrm{c}}$ & $17,47^{\mathrm{c}}$ & $7,43^{\mathrm{c}}$ \\
\hline F4 & $1630,87^{\mathrm{g}}$ & $19,10^{\mathrm{e}}$ & $22,25^{\mathrm{e}}$ & $8,60^{\mathrm{f}}$ \\
\hline F5 & $1471,57^{\mathrm{e}}$ & $18,00^{\mathrm{d}}$ & $24,87^{\mathrm{f}}$ & $8,03^{\mathrm{d}}$ \\
\hline F6 & $1555,87^{\mathrm{f}}$ & $18,10^{\mathrm{e}}$ & $22,62^{\mathrm{e}}$ & $8,34^{\mathrm{e}}$ \\
\hline
\end{tabular}

\section{Keterangan:}

F0 : kareganan 0\%, gum arab 0\%, guar gum 0\%

F1 : kareganan 1\%, gum arab $0 \%$, guar gum $0 \%$

F2 : kareganan $0 \%$, gum arab $1 \%$, guar gum $0 \%$

F3 : kareganan $0 \%$, gum arab $0 \%$, guar gum $1 \%$

F4 : kareganan $0,5 \%$, gum arab $0,25 \%$, guar gum $0,25 \%$

F5 : kareganan $0,25 \%$, gum arab $0,5 \%$, guar gum $0,25 \%$

F6 : kareganan $0,25 \%$, gum arab $0,25 \%$, guar gum $0,5 \%$

*: Angka yang diikuti huruf yang berbeda pada kolom yang sama menunjukkan adanya beda nyata pada taraf sig. $=0,05$ 


\section{Padatan Terlarut}

Padatan terlarut diukur dengan menggunakan handrefraktrometer. Berdasarkan Tabel 1 jumlah dan konsentrasi bahan penstabil berbeda nyata. Hasil uji didapatkan semakin tinggi konsentrasi karagenan pada campuran bahan penstabil, maka padatan terlarut menigkat. Hasil padatan terlarut banyak yaitu karagenan $0,5 \%$, gum arab $0,25 \%$, dan guar gum $0,25 \%$, karena karagenan tersusun atas galaktosa dan 3,6 anhidrogalaktosa, keduanya dihubungkan oleh ikatan glikosidik $\alpha(1,3)$ dan $\beta(1,4)$, mudah larut dalam air, dan memiliki kemampuan mengikat air yang baik (Diharmi dkk, 2011) dan (Imeson, 2010).

\section{Overrun}

Berdasarkan Tabel 1 jumlah dan konsentrasi bahan penstabil berbeda nyata. Hasil uji didapatkan semakin tinggi konsentrasi gum arab pada campuran bahan penstabil, maka overrun terus meningkat. Hasil overrun tertinggi yaitu karagenan $0,25 \%$, gum arab $0,5 \%$, dan guar gum $0,25 \%$, karena gum arab mempunyai viskositas rendah sehingga udara yang terperangkap banyak dan meningkatkan volume. Penambahan volume pada velva terjadi saat proses mixing dengan menggunakan ICM yang diakibatkan oleh terperangkapnya udara pada proses pembekuan, udara yang terperangkap pada adonan akan meningkatkan volume (Safitri dkk, 2017).

\section{Lama Leleh}

Lama leleh adalah waktu yang diperlukan velva untuk meleleh sempurna di suhu ruang. Berdasarkan Tabel 1 jumlah dan konsentrasi bahan penstabil berbeda nyata. Hasil uji didapatkan semakin tinggi konsentrasi karagenan pada campuran bahan penstabil, maka overrun terus meningkat. Hasil dari leleh lama disuhu ruang yaitu karagenan $0,5 \%$, gum arab $0,25 \%$, dan guar gum $0,25 \%$, karena karagenan mempunyai viskositas tinggi sehingga mampu mengikat air bebas dalam velva. Karagenan mudah mengikat air karena mempunyai gugus sulfat bermuatan negatif disepanjang rantai polimernya. Gugus ester sulfat dan unit galaktopiranosa yang terdapat pada karagenan bersifat hidrofilik, maka air bebas akan berkurang dan membentuk struktur gel kuat (Fauziah dkk, 2016). aka dari itu semakin tinggi viskositas dan semakin rendah kadar air membuat velva bertahan disuhu ruang

\section{Karakteristik Kimia}

\section{Kadar Air}

Kadar air adalah jumlah air yang terkandung dalam bahan. Air adalah substansi kimia yang tersusun atas dua molekul hidrogen yang terikat secara kovalen dengan 1 molekul oksigen (Rauf, 2015). Berdasarkan Tabel 2 kadar air velva buah melon memiliki perbedaan nyata. Hasil kadar air terendah yaitu karagenan $0,5 \%$, gum arab $0,25 \%$, dan guar gum $0,25 \%$, karena karagenan mempunyai sifat mudah mengikat air bebas karenanya mempunyai gugus sulfat yang bermuatan negatif disepanjang rantai polimernya. Daya ikat air yang tinggi pada karagenan akan efektif dalam pembentukan tekstur yang halus untuk memperbaiki struktur es krim. Semakin banyak karagenan yang ditambakan akan semakin rendah kadar air bebas yang terkandung dan struktur gel yang terbentuk semakin kuat ((Fauziah dkk, 2016), (Putri dkk, 2014)).

\section{Kadar Vitamin C}

Kadar vitamin $\mathrm{C}$ diuji dengan menggunakan titrasi iodometri. Berdasarkan Tabel 2 kadar vitamin $\mathrm{C}$ velva buah melon memiliki perbedaan nyata. Formulasi yang dapat mempertahankan vitamin $\mathrm{C}$ yaitu karagenan $0,5 \%$, gum arab $0,25 \%$, dan guar gum $0,25 \%$, karagenan dapat mempertahankan vitamin $\mathrm{C}$ pada velva karena bahan penstabil mampu mempertahankan vitamin $\mathrm{C}$ dengan cara manarik partikel-pertikel koloid maka akan sedikit oksigen bebas yang akan menyebabkan oksidasi ((Kumalasari dkk, 2015), (Farikha dkk, 2013)). 
Tabel 2 Hasil Pengujian Mutu Kimia

\begin{tabular}{ccccc}
\hline Formulasi & $\begin{array}{c}\text { Kadar Air } \\
(\%)^{*}\end{array}$ & $\begin{array}{c}\text { Kadar Vitamin C } \\
(\mathrm{mg} / 100 \mathrm{~g})^{*}\end{array}$ & $\begin{array}{c}\text { Kadar Serat } \\
\text { Pangan }(\%)^{*}\end{array}$ & $\begin{array}{c}\text { Aktivitas } \\
\text { Antioksidan }(\%)^{*}\end{array}$ \\
\hline F0 & $85,17^{\mathrm{f}}$ & $19,44^{\mathrm{a}}$ & $1,35^{\mathrm{a}}$ & $2,70^{\mathrm{a}}$ \\
F1 & $80,61^{\mathrm{d}}$ & $22,22^{\mathrm{c}}$ & $1,67^{\mathrm{b}}$ & $3,70^{\mathrm{b}}$ \\
F2 & $82,52^{\mathrm{e}}$ & $21,32^{\mathrm{b}}$ & $1,84^{\mathrm{c}}$ & $2,90^{\mathrm{a}}$ \\
F3 & $80,98^{\mathrm{d}}$ & $21,58^{\mathrm{b}}$ & $2,07^{\mathrm{d}}$ & $3,20^{\mathrm{a}}$ \\
F4 & $77,61^{\mathrm{a}}$ & $22,45^{\mathrm{c}}$ & $2,31^{\mathrm{e}}$ & $3,98^{\mathrm{b}}$ \\
F5 & $79,69^{\mathrm{c}}$ & $22,33^{\mathrm{c}}$ & $2,37^{\mathrm{ef}}$ & $3,71^{\mathrm{b}}$ \\
F6 & $78,12^{\mathrm{b}}$ & $22,28^{\mathrm{c}}$ & $2,52^{\mathrm{f}}$ & $3,77^{\mathrm{b}}$ \\
\hline
\end{tabular}

Keterangan:

F0 : kareganan 0\%, gum arab $0 \%$, guar gum $0 \%$

F1 : kareganan $1 \%$, gum arab $0 \%$, guar gum $0 \%$

F2 : kareganan $0 \%$, gum arab $1 \%$, guar gum $0 \%$

F3 : kareganan $0 \%$, gum arab $0 \%$, guar gum $1 \%$

F4 : kareganan $0,5 \%$, gum arab $0,25 \%$, guar gum $0,25 \%$

F5 : kareganan $0,25 \%$, gum arab $0,5 \%$, guar gum $0,25 \%$

F6 : kareganan $0,25 \%$, gum arab $0,25 \%$,guar gum $0,5 \%$

*: Angka yang diikuti huruf yang berbeda pada kolom yang sama menunjukkan adanya beda nyata pada taraf sig. $=0,05$

\section{Kadar Serat Pangan}

Serat pangan adalah bagian dari bahan pangan yang tidak dapat dihirolisis oleh enzim-enzim pencernaan. Serat sebagai bagian integral dari bahan pangan yang dikonsumsi sehari-hari dengan sumber utama dari tanaman, sayur-sayuran, sereal, buahbuahan, kacang-kacangan (Silalahi dan Hutagalung, 2010). Berdasarkan Tabel 2 kadar serat pangan velva buah melon memiliki perbedaan nyata. Formulasi yang mempunyai kadar serat pangan terbanyak yaitu karagenan $0,25 \%$, gum arab $0,25 \%$, dan guar gum $0,5 \%$, karena guar gum merupakan salah satu zat aditif makanan sebagai sumber serat, pada usus serat larut air guar gum membantu transisi usus. Total serat pangan pada guar gum yaitu $86.2 \mathrm{gr} / 100 \mathrm{gr}$ (Cummings et al, 1978).

\section{Aktivitas Antioksidan}

Berdasarkan Tabel 2 aktivitas antioksidan mempunyai perbedaan nyata. Formulasi velva buah melon yang dapat mempertahankan aktivitas antioksidan yaitu karagenan $0,5 \%$, gum arab $0,25 \%$, dan guar gum $0,25 \%$, karena karagenan memiliki gugus hidroksil yang banyak sehingga untuk membentuk struktur double helix akan lebih tinggi dan melindungi senyawa antioksidan dalam matriks tiga dimensi dari oksigen dan panas (Febriyanti, dan Yunianta, 2015).

\section{Karakteristik Organoleptik}

\section{Aroma}

Aroma pada suatu makanan atau minuman memegang peran penting pada penilaian suatu produk. Aroma yang khas yang ada pada makanan akan dapat mudah dengan mudah dicium oleh indra penciuman tergantung pada bahan penyusunnya, misalnya faktor pengolahan yang berbeda makan akan menimbulkan aroma yang berbeda (Rismawati dkk, 2015). Berdasarkan Tabel 3 hasil uji organoleptik aroma mempunyai perbedaan nyata. Aroma yang paling disukai yaitu karagen $0,25 \%$, gum arab $0,5 \%$, guar gum $0,25 \%$, karena gum arab memiliki sifat yang baik yaitu mempertahankan aroma (Praseptiangga dkk, 2016). 
Tabel 3 Hasil Uji Sensoris

\begin{tabular}{cccccc}
\hline Formulasi & Aroma $^{*}$ & Rasa $^{*}$ & Tekstur* $^{*}$ & Warna $^{*}$ & Overall $^{*}$ \\
\hline F0 & $2,04^{\mathrm{a}}$ & $1,84^{\mathrm{a}}$ & $1,96^{\mathrm{a}}$ & $2,04^{\mathrm{a}}$ & $2,52^{\mathrm{a}}$ \\
F1 & $2,16^{\mathrm{a}}$ & $3,68^{\mathrm{cd}}$ & $3,72^{\mathrm{b}}$ & $4,24^{\mathrm{d}}$ & $3,92^{\mathrm{b}}$ \\
F2 & $2,88^{\mathrm{b}}$ & $3,40^{\mathrm{bc}}$ & $2,32^{\mathrm{a}}$ & $4,48^{\mathrm{d}}$ & $3,72^{\mathrm{b}}$ \\
F3 & $2,12^{\mathrm{a}}$ & $2,28^{\mathrm{a}}$ & $3,92^{\mathrm{bc}}$ & $2,56^{\mathrm{ab}}$ & $2,64^{\mathrm{a}}$ \\
F4 & $3,16^{\mathrm{bc}}$ & $4,08^{\mathrm{d}}$ & $4,32^{\mathrm{c}}$ & $3,88^{\mathrm{cd}}$ & $4,24^{\mathrm{b}}$ \\
F5 & $3,60^{\mathrm{c}}$ & $3,88^{\mathrm{cd}}$ & $3,32^{\mathrm{b}}$ & $3,44^{\mathrm{c}}$ & $3,92^{\mathrm{b}}$ \\
F6 & $2,04^{\mathrm{a}}$ & $2,96^{\mathrm{b}}$ & $3,80^{\mathrm{bc}}$ & $2,76^{\mathrm{b}}$ & $3,08^{\mathrm{a}}$ \\
\hline
\end{tabular}

Keterangan::

$1 \quad$ : Sangat tidak disukai

2 : Tidak disukai

3 : Netral

$4 \quad$ : Suka

$5 \quad$ : Sangat suka

F0 : kareganan $0 \%$, gum arab $0 \%$, guar gum $0 \%$

F1 : kareganan $1 \%$, gum arab $0 \%$, guar gum $0 \%$

F2 : kareganan $0 \%$, gum arab $1 \%$, guar gum $0 \%$

F3 : kareganan $0 \%$, gum arab $0 \%$, guar gum $1 \%$

F4 : kareganan $0,5 \%$, gum arab $0,25 \%$,guar gum $0,25 \%$

F5 : kareganan $0,25 \%$, gum arab $0,5 \%$, guar gum $0,25 \%$

F6 : kareganan $0,25 \%$, gum arab $0,25 \%$,guar gum $0,5 \%$

*: Angka yang diikuti huruf yang berbeda pada kolom yang sama menunjukkan adanya beda nyata pada taraf sig. $=0,05$

\section{Rasa}

Rasa merupakan keputusaan akhir konsumen untuk menentukan produk tersebut dapat diterima atau tidak. Meski parameter nilai parameter yang lain baik, tetapi rasa menentukan produk tersebut diteriama atau tidak oleh konsumen (Thariq dkk, 2014). Berdasarkan Tabel $\mathbf{3}$ hasil uji organoleptik rasa mempunyai perbedaan nyata. Rasa yang paling disukai yaitu karagen $0,5 \%$, gum arab $0,25 \%$, guar gum $0,25 \%$, karena semakin tinggi penambahan karagenan maka akan meningkatkan kandungan gula pada es krim (Fatoni, 2017). Penilai panelis terhadap kesukan terhadap rasa dapat dipengaruhi oleh beberapa faktor. Faktor yang mempengaruhi rasa yaitu konsentrasi, suhu, dan interaksi komponen lain (Putri dkk, 2014. Gula dan asam sitrat juga dapat mempengaruhi rasa karena gula merupakan karbohidrat yang mudah larut dalam air, mempunyai rasa manis dan mudah dicerna oleh tubuh. Gula pada makanan beku berfungsi pemberi rasa manis. Asam sitrat dapat digunakan untuk mestabilkan rasa, tekstur, warna, berperan sebagai pengawet ((Agustin dan Putri, 2014), (Fuia, 1977)).

\section{Tekstur}

Tekstur adalah keadaan partikel-partikel yang menyusun body ice cream (Hartatie,
2011). Berdasarkan Tabel 3 hasil uji organoleptik tekstur mempunyai perbedaan nyata. Tekstur yang paling disukai yaitu karagen $0,5 \%$, gum arab $0,25 \%$, guar gum $0,25 \%$, semakin tinggi penggunaan karagenan pada pembuatan es krim maka tekstur es krim akan meningkatkan, karena sifat karagenan yang sangat baik dalam mengikat air (Masyukuri dan Wibowo, 2009). Tekstur pada produk akhir pengaruhi oleh padatan terlarut, konsentrasi gula, kekentalan, dan resistensi pelelehan (Nurjanah, 2003).

\section{Warna}

Warna merupakan daya tarik utama untuk menarik konsumen dalam mengonsumsi produk makanan tersebut. Berdasarkan Tabel 3 hasil uji organoleptik warna mempunyai perbedaan nyata. Warna yang paling disukai yaitu karagen $0 \%$, gum arab $1 \%$, guar gum $0 \%$, karena gum arab mempunyai warna putih saat menjadi tepung dan saat dilarutkan dengan air menjadi warna bening, sehingga penambahan gum arab tidak akan mempengaruhi warna velva yang dihasilkan (Christiana dkk, 2015). Selain bahan penstabil yang dapat mempengaruhi warna pada velva buah melon, keadaan lingkungan disekitar tempat pengujian produk juga mempengaruhi seperti cahaya 
lampu diruang evaluasi seragam, dekorasi ruang harus netral tidak ada dekorasi yang warna-warni, ukuran dan bentuk produk dapat mempengaruhi visual produk (Jumri dkk, 2015).

\section{Overall}

Berdasarkan Tabel 3 yang meliputi warna, aroma, rasa, tekstur, dan overall memiliki perbedaan nyata. Meskipun ada perbedaan nyata dari setiap parameter, paling diterima oleh konsumen yaitu karagenan $0,5 \%$, gum arab $0,25 \%$, guar gum $0,25 \%$, karena yang mempengaruhi mutu velva yang utama yaitu tekstur. Velva yang ideal yaitu memiliki tekstur lembut, partikel-partikel bahan terlalu kecil untuk dideteksi mulut (Basito dkk, 2018).

\section{Uji Pembobotan}

Berdasarkan Tabel 4 uji pembobotan menunjukkan bahwa bobat variable memiliki nilai 0.75 dan 1 . Nilai 1 diberikan kepada mutu fisik seperti viskositas, lama leleh, padatan terlarut, overrun karena mutu fisik memiliki konstribusi yang besar dalam keberhasilan dalam membentuk body velva buah melon. Berdasarkan hasil uji pembobotan nilai hasil tertinggi $(\mathrm{NH})$ yaitu formulasi karagenan 0,5\%, gum arab 0,25\%, guar gum $0,25 \%$ nilai sebesar 0,86 . Kombinasi karagenan, gum arab, dan guar gum memiliki sifat saling mendukung dan dapat memperbaiki kelemahan yang dimiliki oleh salah satu bahan penstabil sehingga mampuh mencegah pembentukan kristal es krim yang besar, memperbaiki tekstur es krim, tidak cepat meleleh, dan menghasilkan warna alami velva (Lestari, 2017).

Tabel 4 Hasil Uji Pembobotan

\begin{tabular}{|c|c|c|c|c|c|c|c|c|c|c|c|c|c|c|c|c|}
\hline \multirow{2}{*}{ Parameter } & \multirow{2}{*}{ BV } & \multirow{2}{*}{$\mathrm{BN}$} & \multicolumn{2}{|c|}{ F0 } & \multicolumn{2}{|c|}{ F1 } & \multicolumn{2}{|c|}{ F2 } & \multicolumn{2}{|c|}{ F3 } & \multicolumn{2}{|c|}{ F4 } & \multicolumn{2}{|c|}{ F5 } & \multicolumn{2}{|c|}{ F6 } \\
\hline & & & $\mathrm{NE}$ & $\mathrm{NH}$ & $\mathrm{NE}$ & $\mathrm{NH}$ & $\mathrm{NE}$ & $\mathrm{NH}$ & $\mathrm{NE}$ & $\mathrm{NH}$ & $\mathrm{NE}$ & $\mathrm{NH}$ & $\mathrm{NE}$ & $\mathrm{NH}$ & $\mathrm{NE}$ & $\mathrm{NH}$ \\
\hline Viskositas & 1,00 & 0,09 & & 0,00 & 0,82 & 0,08 & 0,47 & 0.04 & 0,72 & 0,07 & 1,00 & 0,09 & 0,83 & 0,08 & 0,92 & 0,09 \\
\hline $\begin{array}{l}\text { Padatan } \\
\text { terlarut }\end{array}$ & 1,00 & 0,09 & 0,00 & 0,00 & 0,86 & 0,08 & 0,46 & 0,04 & 0,46 & 0,04 & 1,00 & 0,09 & 0,90 & 0,08 & 0,91 & 0,08 \\
\hline Overrun & 1,00 & 0,09 & 0,00 & 0,00 & 0,43 & 0,04 & 0,63 & 0,06 & 0,49 & 0,05 & 0,82 & 0,08 & 1,00 & 0,09 & 0,85 & 0,08 \\
\hline Daya leleh & 1,00 & 0,09 & 0,00 & 0,00 & 0,58 & 0,05 & 0,25 & 0.02 & 0,51 & 0,05 & 1,00 & 0,09 & 0,76 & 0,07 & 0,89 & 0,08 \\
\hline Kadar air & 0,75 & 0,07 & 1,00 & 0,07 & 0,40 & 0,03 & 0,65 & 0,05 & 0,45 & 0,03 & 0,00 & 0,00 & 0,27 & 0,02 & 0,07 & 0,00 \\
\hline $\begin{array}{l}\text { Kadar serat } \\
\text { Kadar }\end{array}$ & 0,75 & 0,07 & 0,00 & 0,00 & 0,27 & 0,02 & 0,41 & 0,03 & 0,61 & 0,04 & 0,82 & 0,06 & 0,87 & 0,06 & 1,00 & 0,07 \\
\hline Vitamin C & 0,75 & 0,07 & 0,00 & 0,00 & 0,92 & 0,06 & 0,62 & 0,04 & 0,71 & 0,05 & 1,00 & 0,07 & 0,96 & 0,07 & 0,94 & 0,07 \\
\hline $\begin{array}{l}\text { Aktivitas } \\
\text { antioksidan }\end{array}$ & 0,75 & 0,07 & 0,00 & 0,00 & 0,78 & 0,05 & 0,15 & 0,01 & 0,39 & 0,03 & 1,00 & 0,07 & 0,78 & 0,05 & 0,83 & 0,06 \\
\hline Aroma & 0.75 & 0,07 & 0,00 & 0,00 & 0,08 & 0,01 & 0,54 & 0,04 & 0,05 & 0,00 & 0,72 & 0,05 & 1,00 & 0,07 & 0,00 & 0,00 \\
\hline Rasa & 0,75 & 0,07 & 0,00 & 0,00 & 0,82 & 0,06 & 0,70 & 0,05 & 0,20 & 0,01 & 1,00 & 0,07 & 0,91 & 0,06 & 0,50 & 0,03 \\
\hline Tekstur & 0,75 & 0,07 & 0,00 & 0,00 & 0,75 & 0,05 & 0,15 & 0,01 & 0,83 & 0,06 & 1,00 & 0,07 & 0,58 & 0,04 & 0,78 & 0,05 \\
\hline Warna & 0,75 & 0,07 & 0,00 & 0,00 & 0,90 & 0,06 & 1,00 & 0,07 & 0,21 & 0,01 & 0,75 & 0,05 & 0,57 & 0,04 & 0,30 & 0,02 \\
\hline Overall & 0,75 & 0,07 & 0,00 & 0,00 & 0,81 & 0,06 & 0,70 & 0,05 & 0,07 & 0,00 & 1,00 & 0,07 & 0,81 & 0,06 & 0,33 & 0,02 \\
\hline Jumlah & 10,75 & 1,00 & & 0,07 & & 0,65 & & 0,51 & & 0,45 & & 0,86 & & 0,80 & & 0,66 \\
\hline
\end{tabular}

Keterangan :

BV : Bobot variable $\quad \mathrm{NH}$ : Nilai hasil

BN : Bobot normal NE : Nilai efektivitas

\section{KESIMPULAN}

Berdasarkan penilitian jenis dan konsentrasi penstabil terhadap mutu fisik, kimia, dan sensoris velva buah melon maka diperoleh hasil formulasi terbaik yaitu karagenan $0,5 \%$, gum arab $0,25 \%$, guar gum $0,25 \%$, mutu fisik viskositas mencapai $1630.87 \mathrm{cP}$, padatan terlarut mencapai $19,10^{\circ}$ Brix, overrun mencapai $24,87 \%$, dan lama leleh mencapai 8,60 menit. Mutu kimia formulasi terbaik yaitu kombinasi karagenan $0,5 \%$, gum arab $0,25 \%$, guar gum $0,25 \%$ yang diperoleh kadar air mencapai $77.61 \%$, kadar vitamin C 22,45 mg/100gr, kadar serat pangan 2,31\%, dan aktivitas antioksidan $3,98 \%$. Sensoris diperoleh hasil yaitu aroma 3,60 ; rasa 4,08; tekstur 4,32; warna 4,48, dan overall 4,24 .

\section{DAFTAR PUSTAKA}

Agustin, F., dan Putri, W. D. R. 2014. Pembuatan Jelly Drink Averrhoa blimbi L (Kajian Proporsi Belimbing Wuluh: 
Air dan Konsentrasi Karagenan). Jurnal Agroindustri, 2(3): 1-9.

AOAC 1995 Official Method of Analysis of The Association of Official Analytical Chemist (Washington, D.C : Benyamin Franklin Stasion)

Arbuckle, W. S. 1986. Ice Cream Fourth Edition. Springer Science + Business Media. New York.

Basito., Yudhistira, B., dan Meriza, D. A. 2018. Kajian Penggunaan Bahan Penstabil CMC (Carboxil MethylCellulosa) dan Karagenan Dalam Pembuatan Velva Buah Naga Super Merah (Hylocereus costaricensis). Jurnal Teknologidan Industri Pertanian Indonesia, 10(01): 42-49.

Bodyfelt F W, Tobias J and Trout G 1998.The Sensory Evaluation of Dairy Product. AVI Publishing company Westport Connecticut

Christiana, M. A., Radiati, L. E., dan Purwadi. 2015. Pengaruh GumArab pada Minuman Madu Sari Apel Ditinjau dari Mutu Organoleptik, Warna, pH, Viskositas, dan Kekeruhan. Jurnal Ilmu dan Teknologi Hasil Ternak, 10(2): 4653.

Cummings, J. H., Branch, W., Jenkins, D. J. A., Southgate, D. A. T., Houston, H., dan James, W. P. T. 1978. Colonic Response to Dietary Fibre From Carrot, Cabbage, Apple, Bran, and Guar gum. The Lancet, 311(8054): 5-9.

Asp N G, Johanson C G, Halmer H, and Siljestrom M 1983 Rapyd enzimatic assay of insoluble and soluble diatary fiber J. Agric. Food.Chem 31 476-482

Diharmi, A., Fardiaz, D., Andarwulan, N., dan Heruwati, E. S. 2011. Karakteristik Karagenan Hasil Isolasi Eucheuma spinosum (Alga merah) dari Perairan Semenep Madura. Jurnal Perikanan dan Kelautan, 16(1): 117-124.

Farikha, I. N., Anam, C., dan Widowati, E. 2013. Pengaruh Jenis dan Konsentrasi Bahan Penstabil Alami Terhadap Karakteristik Fisikokimia Sari Buah Naga Merah (Hylocereus polyrhizus)
Selama Penyimpanan. Jurnal Teknosains Pangan, 2(1): 30-38.

Fatoni, M., Basuki, E., \& Prarudiyanto, A. 2017. Pengaruh Penambahan Karagenan Terhadap Beberapa Komponen Mutu Es Krim Labu Kuning (Cucurbita moschata). Pro Food, 2(2): 158-164.

Fauziah, E., Widowati, E., dan Atmaka, W. 2016. Kajian Karakteristik Sensoris dan Fisikokimia Fruit Leather Pisang Tanduk (Musa corniculata) dengan Penambahan Berbagai Konsentrasi Karagenan. Jurnal Aplikasi Teknologi Pangan, 4(1): 11-16.

Febriyanti, S., dan Yunianta, Y. 2015. Pengaruh Konsentrasi Karagenan dan Rasio Sari Jahe Emprit (Zingiber officinale var. Rubrum) Terhadap Sifat Fisik, Kimia, dan Organoleptik Jelly Drink Jahe [In Press April 2015]. Jurnal Pangan dan Agroindustri, 3(2): 542550.

Furia, T. E. 1977. Handbook of Food Addictive $\left(e d .2^{\text {th }}\right)$. CRC Press. Florida.

Hartatie, E. S. 2011. Kajian Formulasi (Bahan Baku, Bahan Pemantap) dan Metode Pembuatan Terhadap Kualitas Es Krim. Jurnal Gamma, 7(1): 20-26.

Imeson, A. 2010. Food Stabilisers, Thickeners and Gelling Agents. Blackwell Publishing Ltd. USA.

Jumri., Yusmarini., dan Herawati, N. 2015. Mutu Permen Jelli BuahNaga Merah (Hylocereus Polyrhizus) dengan Penambahan Karagenan daan Gum Arab. Jurnal Online Mahasiswa (JOM) Bidang Pertanian, 2(1): 1-10.

Kumalasari, R., Ekafitri, R., dan Desnilasari, D. 2015. Pengaruh Bahan Penstabil dan Perbandingan Bubur Buah Terhadap Mutu Sari Buah Campuran PepayaNanas. Jurnal Hortikultura, 25(3): 266276.

Larmond E .1977. Laboratory Methods for Sensory Evaluation of Food. Research Branch, Canada, Department of Agriculture, Ottawa Publication 
Lestari, S. D., Ayu, D. F., dan Rahmayuni, R. 2017. Pengaruh Kombinasi CMC dan Gum Arab terhadap Mutu Sensori Velva Ubi Jalar Ungu. Jurnal Online Mahasiswa (JOM) Bidang Pertanian, 4(2): 1-11.

Marshall R T and Arbuckle W S 1996 Ice Cream New York: Chapman and Hill

Masyukuri, N., dan Wibowo, R. A. 2009. Pengaruh Penggunaan Karagenan Sebagai Penstabil Terhadap Kondisi Fisik dan Tingkat kesukaan pada Es Krim Cokelat. In Seminar Nasional Kebangkitan Peternakan. Semarang.

Nuraini, D. 2001. Peran Hidrokoloid dalam Industri Pangan. Journal of AgrBased Industry, 8(1-2): 37-47.

Nurjanah, E. 2003. Pengaruh Jenis dan Konsentrasi Bahan Penstabil Terhadap Mutu Velva Wortel (Daucus carota L.). Skripsi Jurusan Gizi Masyarakat dan Sumber Daya Keluarga Fakultas Pertanian, Institut Pertanian Bogor.

Praseptiangga, D., Aviany, T. P., dan Parnanto, N. H. R. 2016. Pengaruh Penambahan Gum Arab Terhadap Karakteristik Fisikokimia dan Sensoris Fruit Leather Nangka (Artocarpus heterophyllus). Jurnal Teknologi Hasil Pertanian, 9(1): 139-148.

Putri, V. N., Susilo, B., dan Hendrawan, Y. 2014. Pengaruh Penambahan Tepung Porang (Amorphophallus onchophyllus) pada Pembuatan Es Krim Instan Ditinjau dari Kualitas Fisik dan Organoleptik. Jurnal Keteknikan Pertanian Tropis dan Biosistem, 2(3): 188-197.

Rauf, R. 2015. Kimia Pangan. Penerbit Andi. Yogyakarta.

Regand, A dan Goff. H.D. 2003. Structure and Ice Crystallization in Frozen Stabilized Ice Cream Model System. Food Hydrocolloids 17: 95-102.

Rismawati, F., Leni, L. H. A., dan Ina, S. D. 2015. Pengaruh Perbandingan Air Dengan Buah Salak dan Konsentrasi Penstabil Terhadap Karakteristik
Minuman Sari Buah Salak Bongkok (Salacca edulis, Reinw). Artikel, Fakultas Teknik, Universitas Pasundan, Bandung.

Safitri, A. D., Mardiah., dan Hutami, R. 2017. Penggunaan Bahan Penstabil pada Mutu Velva Rosela (Hibiscus sabdariffa L.) dengan Pemanis Madu. Jurnal Agroindustri Halal, 3(1): 010-018.

Sullivan, William G, Elin M Wicks dan C Patrick Koelling. Engineering Economy: Sixteenth Edition. Pearson. Virginia

Silalahi, J dan Hutagalung, N. 2010. Komponen-komponen Bioaktif dalam Makanan dan Pengaruhnya Terhadap Kesehatan. Dalam: Santoso, I. A. 2011. Serat Pangan (Dietary Fiber) dan Manfaatnya Bagi Kesehatan. Magistra, 23(75): 35 .

Tantono, E., Effendi, R., dan Hamzah, F. H. 2017. Variasi Rasio Bahan Penstabil CMC (Carboxy Methyl Cellulose) dan Gum Arab Terhadap Mutu Velva Alpukat (Parsea americana Mill.). Jurnal Online Mahasiswa (Jom) Faperta, 4(2): 1-15.

Thariq, A. S., Swastawati, F., dan Surti, T. 2014. Pengaruh Perbedaan Konsentrasi Garam pada Peda Ikan Kembung (Rastrelliger neglectus) Terhadap Kandungan Asam Glutamat Pemberi Rasa Gurih (Umami). Jurnal Pengolahan dan Bioteknologi Hasil Perikanan, 3(3): 104-111.

USDA. 2016. Basic Report 09181, Melons, Cantaloupe, Raw.

Violisa, A., Nyoto, A., dan Nurjanah, N. 2012. Penggunaan Rumput Laut Sebagai Stabilizer Es Krim Susu Sari Kedelai. Teknologi dan Kejuruan, 35(1): 103-114. 